IFN Working Paper No. 775, 2008

\title{
Intergenerational Top Income Mobility in Sweden - Capitalist Dynasties in the Land of Equal Opportunity?
}

Anders Björklund, Jesper Roine and Daniel Waldenström 


\title{
Intergenerational top income mobility in Sweden:
}

\section{Capitalist dynasties in the land of equal opportunity? ${ }^{*}$}

\author{
Anders Björklund \\ Swedish Institute for Social Research (SOFI) and IZA \\ Stockholm University \\ Jesper Roine \\ SITE, Stockholm School of Economics \\ Daniel Waldenström \\ Research Institute of Industrial Economics (IFN)
}

September 27, 2010

\begin{abstract}
This paper presents new evidence on intergenerational mobility in the top of the income and earnings distribution. Using a large dataset of matched father-son pairs in Sweden, we find that intergenerational transmission is very strong in the top, more so for income than for earnings. In the extreme top (top 0.1 percent) income transmission is remarkable with an IG elasticity above 0.9 . We also study potential transmission mechanisms and find that sons' IQ, non-cognitive skills and education are all unlikely channels in explaining this strong transmission. Within the top percentile, increases in fathers' income are, if anything, negatively associated with these variables. Wealth, on the other hand, has a significantly positive association. Our results suggest that Sweden, known for having relatively high intergenerational mobility in general, is a society where transmission remains strong in the very top of the distribution and that wealth is the most likely channel.
\end{abstract}

Keywords: Intergenerational income mobility, top incomes, earnings inequality, income inequality, welfare state, quantile regression

JEL: D31, J62

\footnotetext{
* This paper is an extended version of Björklund, Roine and Waldenström (2008). We are grateful to Robert Erikson, Markus Jäntti, Philipe van Kerm, Thomas Piketty, Tim Smeeding and seminar participants in Stockholm (SOFI, Stockholm University, and IFN), Bergen (NHH), Bonn (IZA), Université Libre de Bruxelles, and the IARIW conference 2010 for constructive comments. Björklund acknowledges research funding from Swedish Council for Working Life and Social Research (FAS), Roine and Waldenström from the Jan Wallander and Tom Hedelius Foundation, and Waldenström also from the Gustaf Douglas Research Program on entrepreneurship at IFN.
} 


\section{Introduction}

This paper studies intergenerational income mobility focusing on the top of the distribution. More precisely, we study the income association of matched father-son pairs, based on a representative sample of all men born in Sweden in 1960-1967. Our sample consists of more than 100,000 pairs (35 percent of that population), which means that we are able to get good precision estimates for fractions as small as 0.1 percent of the income distribution.

There are two main motivations for this study. The first is based on the growing literature on top income shares over the long run. ${ }^{1}$ Besides giving us new comparable long-run series of inequality, this literature has also shown the importance of studying the top in more detail in order to understand aspects of overall inequality. ${ }^{2}$ In particular, it has been shown that the recent surge in inequality in many countries has been driven mainly by large income increases in the top percent (or even smaller fractions). However, so far this literature has not explicitly studied intergenerational mobility. Understanding mobility is crucial for evaluating inequality in general, and the same obviously applies for the recent increase in top income shares. Indeed, when asked about the fairness of high income concentration, most people respond that it crucially depends on how those in the top got there. If success depends on "hard work" or being "more skillful", people seem to tolerate inequality-even high degrees of it. If, on the other hand, the rich have reached their position because of inheritance, a certain family environment, or "connections and knowing the right people", this is generally viewed as unfair. ${ }^{3}$ Atkinson and Piketty (2007) point out that the change in top income composition in AngloSaxon countries, where top wage earners have replaced capital income earners, indicate that

\footnotetext{
${ }^{1}$ Starting with Piketty (2001), Atkinson (2004), and Piketty and Saez (2003), a number of studies have followed using a common methodology to create homogenous series of top income shares over the long run for a number of mainly industrialized countries. Roine and Waldenström (2008) study the Swedish case. Atkinson and Piketty (2007, 2010) survey much of this work, its methodology and main findings.

${ }^{2}$ For example, the top income literature has shown that the top decile is typically a very heterogeneous group both in terms of income composition (though the composition has also changed over time for some groups) and in terms of the volatility of their income share. For most countries it also seems that most of the movement in the share of the top decile group is, in fact, driven by the top percent, something which runs the risk of not being captured if data is based on smaller, often top-coded samples.

${ }^{3}$ The quotes are formulations from a Gallup poll used in Fong (2001) and questions appearing in the International Social Justice Project, but there are many other examples of similar formulations in, for example, the World Values Survey, the General Social Survey, the International Social Survey, etc. Some studies have focused on the differences in perceptions of why people are rich or poor, and, in particular on the differences between the US and Europe with respect to such beliefs (e.g., Alesina, Glaeser and Sacerdote, 2001, and Alesina and Glaeser, 2004). However, the opinion that if a person is rich as a consequence of working hard this is fair (and vice versa if the person has not made any effort) seems to be shared across countries. For example, Jencks and Tach (2006) report that a majority of people in Germany, Japan, U.K. and the U.S. agreed with the statement that "[inequality] is fair but only if there are equal opportunities" (based on data collected by the International Social Justice Project (ISJP) in 1991).
} 
today's income top is not primarily based on inherited wealth. This is supported by the findings in Kopczuk and Saez (2004), who show that the recent increase in income concentration in the U.S has not been accompanied by any major increase in wealth concentration, and by Edlund and Kopczuk (2008), who proxy wealth mobility in the U.S. by the share of women in the top of the distribution, and find that this share has decreased substantially over the past decades, also indicating a decreasing role for inheritance among the rich. ${ }^{4}$ While these findings are indicative for questions regarding mobility, our study explicitly addresses intergenerational associations of top incomes as well as their potential transmission mechanisms.

The second motivation is based on previous research on intergenerational mobility, and in particular on the studies that have been concerned with nonlinearities. Most of these studies have primarily been interested in differences in mobility patterns across the whole range of the bivariate income distribution. ${ }^{5}$ In contrast, we focus on the top of the distribution and in particular on fractions in the very top that in most of this literature are unusually small. We are aware of only two previous studies that share our level of detail in this respect. First, Corak and Heisz (1999) do a thorough exploration of nonlinearities in intergenerational mobility for both earnings and income using a very large sample of Canadian men. Even if their sample size is large enough for them to be able to study small fractions of the distribution, their primary focus is on nonlinearities over the whole distribution rather than groups within the top. Consequently they choose not to study details of the top in the same way as we do. Second, Finnie and Ervine (2006), who also study Canadian data, are explicitly concerned with top groups. Their study is, however, different in that they look at the "origins" of individuals located in today's top groups by means of a transition matrix. More precisely, they trace the decile in the distribution of family market incomes in the early 1980s, from which individuals in various top groups have originated. We use several models and techniques that are more standard in the intergenerational mobility literature (also including transition matrix-

\footnotetext{
${ }^{4}$ Kopczuk, Saez and Song (2010) study within lifetime income mobility in the U.S. and find that the probability of remaining in the top percent of the distribution from one period to the next has changed very little over the past decades.

${ }^{5}$ For example, Eide and Showalter (1999), Grawe and Mulligan (2002), Couch and Lillard (2004), Grawe (2004), Hertz (2005), Jäntti et al. (2006), and Bratsberg et al. (2007) are all (at least partly) concerned with nonlinear patterns in the overall distribution. Typically, these studies are concerned with differences across quartiles or deciles rather than percentiles or even fractions of percentiles. This is largely driven by the underlying questions (such as the impact on the intergenerational elasticity from credit constraint on educational investments), but also by the fact that studying small fractions of the distribution requires a very large sample.
} 
es). Finally, we also study potential transmission channels, which is something neither of these previous studies examine. ${ }^{6}$

Studying the same fractile groups and using the same income concepts as in the top income literature, we find that: 1) The intergenerational transmission is generally much stronger in the very top of the distribution (the top 1 percentile group). In the extreme top (the top 0.1 percentile group) the transmission is remarkably strong, with intergenerational elasticities above 0.9 in our main specifications. 2) Earnings transmission is also high for these groups but generally lower than that for total income, suggesting that capital may play a key role in explaining the very strong transmission; 3) When studying channels of transmission, we find that sons' IQ, non-cognitive skills, education as well as wealth, all seem to be positively related to fathers' income in the distribution in general. However, in the top percentile this is only true for measures of wealth, which also indicates that the plausible channel of strong transmission in the top is capital. Cognitive skills, non-cognitive skills and education are, if anything, negatively related to fathers' income within the very top of the distribution.

In the next section of the paper we present our data. Section 3 contains our main results on intergenerational income associations in the top using both piecewise linear regressions as well as quantile regressions. We also present transition matrix results as an alternative measures of intergenerational mobility. In section 4 we check the robustness of our main results. In section 5 we explore possible transmission channels (IQ, non-cognitive skills, education and various measures of wealth) and finally, in section 6 we conclude with a discussion of our results and also point to some interesting topics for future research.

\section{Data}

We use Swedish data compiled from administrative registers run by Statistics Sweden. The starting point for constructing our data set is a random sample of 35 percent of all men born in Sweden between 1960 and 1967. These are the sons in our study. Using the multigenerational register we can connect them to their biological fathers, and using income regis-

\footnotetext{
${ }^{6}$ Corak and Heisz (1999)—-like many subsequent studies of nonlinearities—discuss their results in terms of possible borrowing constraints on parental investments in human capital of children, but they do not explicitly study data for this or any other mechanism. Though not explicitly concerned with the top of the distribution, a recent paper by Corak and Piraino (2010) considers a previously overlooked channel. They study to what extent fathers and sons have the same employer and find that this "inheritance of employer" is much more common in the top of the distribution. This could clearly play a role in understanding nonlinearities.
} 
ters we can add annual income data based on compulsory reports from employers to tax authorities or from personal tax returns, to both fathers and sons.

The objective then is to get good estimates of lifetime incomes. For sons we observe their incomes during 1996-2005, i.e., when they are in their 30s and early 40s. This is a period in life when even annual incomes are shown to be unbiased proxies for lifetime income with only classical measurement errors (Böhlmark and Lindquist, 2006). In order to eliminate most of the transitory fluctuations, we average their annual incomes over the entire ten-year period.

When measuring fathers' incomes, we also want a good proxy for long-run income, but there are also arguments for measuring income at the time when their children grew up since this captures important determinants of the intergenerational transmission of incomes. ${ }^{7}$ We meet both these requirements by measuring fathers' income as the average of income during the years 1974-1979, i.e., when their sons were between seven and nineteen years old and thus mostly living with their parents. ${ }^{8}$

We use two concepts of income. The first is total income, which is income from all sources (labor, business, capital and realized capital gains) before taxes and transfers. ${ }^{9}$ This is the same measure as previously used when studying the evolution of top income shares. ${ }^{10}$ Our estimates of intergenerational mobility in the top, thus, correspond directly to the estimates of the static top income inequality. Our second measure is earnings, which includes income from work for employees and self-employed. ${ }^{11}$

There are of course many specific problems that arise when measuring incomes and earnings in the absolute top of the distribution (see Roine and Waldenström (2010) for a detailed discussion). Overall we are broadly confident that the Swedish register data used in this study

\footnotetext{
${ }^{7}$ Several previous studies in the intergenerational literature have chosen to measure fathers' incomes in this way. See Corak (2006), Björklund and Jäntti (2009), and Black and Devereux (2010) for recent surveys.

${ }^{8}$ This choice is also influenced by the fact that fully comparable measures of income and earnings are only available from 1974 onwards. Although we observe incomes since 1968, there was a legal change in 1973-1974 that made a set of social insurance benefits taxable and from then on also included in the income data.

${ }^{9}$ Total income (sammanräknad nettoinkomst for fathers and summa förvärvs- och kapitalinkomst for sons) also includes taxable social insurance benefits such as unemployment insurance, pensions, sickness pay and parental leave benefits.

${ }^{10}$ See Roine and Waldenström (2008).

${ }^{11}$ Earnings (arbetsinkomst) is an income concept created by Statistics Sweden by combing wages and salaries and business income. It also includes earnings-related short-term sickness benefits and parental-leave benefits but not unemployment and (early) retirement benefits.
} 
correctly measure top incomes - for example, income tax reports are not only individual but employers and financial institutions are also by law required to report what they have paid out to individuals and there is no such thing as top coding in the income and earnings registers. In addition, the two most important sources of measurement error that may still be present bias our results downward implying that, if anything, we underestimate the effects that we find. ${ }^{12}$

First, our earnings measure never includes capital incomes even though items such as bonuses and realized stock options can be a relatively important form of compensation to top earners. To the extent that such capital-based reimbursements have become more prevalent since the 1970s, which is arguably the case also in Sweden, we systematically underestimate top earnings among sons. Since this mismeasurement of the dependent variable is likely to be positively correlated with father's earnings, this potentially leads to underestimating the intergenerational transmission for earnings.

Second, after Sweden around 1990 liberalized its capital account there has been a drastic increase in cross-border capital movements among the wealthy. In a recent survey of the Swedish household wealth concentration, Roine and Waldenström (2009) show that significant shares of wealth owned by the richest Swedes may be placed in off-shore locations. As a result, capital income among high-income earning sons could be underestimated. If anything, we again risk underestimating the intergenerational transmission.

In addition to studying the intergenerational transmission of earnings and incomes we are also interested in analyzing potential mechanisms through which this may work. We consider four different channels for which we can obtain good data for the sons in our sample: education, IQ, non-cognitive skills, and wealth. Our measure of education is based on Statistics Sweden's education registry. The variable is available in seven levels that we recode to years of schooling. ${ }^{13}$ Our measures of IQ and non-cognitive ability are obtained from the Swedish military's compulsory enlistment tests that are conducted around age $18 .^{14}$ The IQ test has four

\footnotetext{
${ }^{12}$ More precisely Statistics Sweden's income and earnings data rely on personal tax assessments through 1977 for wages, salaries, and transfers, and through 1987 for interests and dividends. Thereafter reports come from employers (and authorities for transfers) and banks respectively. Thus, our sons' data come from employers and banks and most of our fathers' data come from personal reports. If anything the latter source introduces some measurement error in fathers' income resulting in an underestimation of intergenerational transmission.

${ }^{13}$ We assign 9 years of schooling for compulsory education, 11 for short high school, 12 for long high school, 14 for short university, 15.5 for long university, and 19 for Ph.D.

${ }^{14}$ See Cesarini (2010) and Lindqvist and Vestman (2010) for more information about these tests and evaluations of them for research purposes like the one in this study.
} 
parts (synonyms, inductions, metal folding and technical comprehension), which are reported on a scale from 1 to 9 . The results of the tests are transformed to an overall measure of cognitive ability, also ranging from 1 to 9. The variable follows a Stanine scale that approximates a normal distribution. The measure of non-cognitive skills is the outcome of interviews with the conscripts by certified psychologists. The overall objective of these interviews is to assess the conscripts' ability to cope with the psychological requirements of the military service. The psychologists assign each conscript a score between 1 and 9, and the variable is constructed to follow the Stanine scale with a normal distribution.

We also use three wealth variables. From the wealth register at Statistics Sweden, we retrieve market-valued estimates of net worth and financial assets for all individuals in the country. Financial assets (bank accounts, ownership of stocks, bonds and mutual funds) and debts (any kind) come from statements, which by law must be reported directly by financial firms to the tax authorities. From the housing and property registers all private housing and real estate (except condominiums) are retrieved. We also use taxable wealth, which is reported by individuals on their tax returns, but only available for the ones with sufficiently high wealth to be taxed (roughly the top fifth).

When determining the sample used in the estimations, we begin by requiring fathers to be residents all the years 1974-1979 and sons in all the years 1996-2005. We then use separate samples for income and earnings and use only the father-son pairs for whom both had positive income observations each observation year, and do the corresponding in the earnings sample. ${ }^{15}$ A further requirement in our main samples is that our potential transmission variableseducation, IQ, non-cognitive skills and wealth—do not have missing values. This, together with the requirement of positive values for all years, causes us to lose observations, so we therefore also run some robustness checks to see how the results vary when using different samples and when including observations with reported zero income and earnings (treating the zeros in some alternative ways). ${ }^{16}$

\footnotetext{
${ }^{15}$ Our income and earnings data come in units of 1 SEK for all but two years when they come in 100 SEK. We adjust for this in our analysis by multiplying incomes and earnings in the two latter years by 100 . Still, there may be a concern that when taking logs of incomes near the lowest income limit the initial difference in limits could influence the results. Rerunning the main analysis requiring incomes and earnings to be at least 100 SEK instead of just being positive, however, the results (available upon request) do not change.

${ }^{16}$ These results are reported in Section 4.
} 
Table 1 reports descriptive statistics for the income and earnings samples of our main analysis as well as descriptive statistics for the variables used in the analysis of potential transmission mechanisms. Our income sample contains 108,277 pairs of fathers and sons and the earnings sample contains 85,848 pairs. ${ }^{17}$ Thus we observe more than a thousand father-son pairs in the top income percentile and over one hundred in the top 0.1 percentile group. The mean and median in both the income and earnings samples are about the same for fathers as well as for sons. In the top of the distribution, however, incomes are substantially higher, especially for the sons. This indicates the importance of analyzing earnings and incomes separately, especially when studying the top of the distribution. Coefficients of variation are in line with the previously documented trends for top income shares in Sweden, which indicate sharp increases for total income but only moderate changes for earnings (see Roine and Waldenström, 2008, for details). Also we note that the age of fathers is somewhat higher in the income sample, which is plausible given that few fathers have positive earnings after their retirement at the age of $65 .^{18}$

\section{[Table 1]}

\section{Econometric models and main results}

Our point of departure is the prototypical model in intergenerational income mobility research

$$
y_{s i}=\alpha+\beta y_{f i}+\varepsilon_{i}
$$

where $y_{s i}$ is the natural $\log$ of income of a son in family $i$ and $y_{f i}$ the corresponding measure for his father. ${ }^{19}$ We want to estimate the intergenerational relationship between long-run incomes following the standard approach in the literature, and therefore use multi-year average incomes throughout. We also control for father's and son's age (linearly and quadratically) in all our regressions.

\footnotetext{
${ }^{17}$ These numbers can be compared to 151,148 sons who were born in Sweden in 1960-1967 and resided in Sweden all years 1996-2005, that is, the population we want to make inferences about. Table A1 explains how the sample changes depending on the requirements we have. In section 4 , we examine whether our results are sensitive to these decisions and find that they are not.

${ }^{18}$ By running the analysis using only fathers aged 65 or less in both populations we have confirmed that the fact that fathers in the income sample are relatively older does not influence our results (these estimates are available upon request).

${ }^{19}$ Obviously, it would be interesting to incorporate mothers and daughters too. Here we limit the analysis to father-son relations partly to make comparisons with previous studies more straightforward but mainly for data coverage reasons.
} 
The regression coefficient $\beta$ is the intergenerational elasticity, i.e., it measures the percentage differential in sons' expected income with respect to a marginal percentage differential in the incomes of fathers. In case the variance of long-run incomes in both generations is the same, the elasticity is also the intergenerational correlation in log incomes. In our study, the distinction between the elasticity and the correlation is not relevant since we focus on the intergenerational transmission in the top of the distributions.

We extend equation (1) in two ways to address two different questions. ${ }^{20}$ First, we run separate LS-regressions across different father fractiles. More specifically, we run equation (1) separately for those father-son pairs where the fathers' income is in the P0-P90, P90-P95, P95-99, P99-P99.9, and P99.9-100 respectively. The interpretation of the coefficient $\beta$ for each of these regressions is, hence, the percentage differential in sons' expected income with respect to a marginal percentage differential in the incomes of fathers given that the father had an income in the respective fractile group. ${ }^{21}$

Our second approach is to use quantile regressions to analyze how sensitive the Qth percentile in sons' income distribution is to fathers' incomes (see Koenker and Hallock, 2001). When Q is a top income quantile, say the 99th percentile, our estimated parameter tells us how sensitive the top in sons' income distribution is to differentials in fathers' incomes. Thus we specify the following equation for each conditional quantile Q:

$$
y_{s i}=\alpha^{Q}+\beta^{Q} y_{f i}+\varepsilon_{i}^{Q}
$$

Our main results from the LS-regressions across father income fractiles are reported in Table 2. The conventional least squares regression model (1) yields estimates of the intergenerational elasticity of 0.260 for income and 0.168 for earnings when using all observations over the

\footnotetext{
${ }^{20}$ Grawe (2004) uses a model that combines two approaches close to ours, namely spline and quantile regression. However, this combination is not feasible for us as our focus on the very top of the distribution gives small samples.

${ }^{21}$ In a previous version of this paper we used a spline function with knots (chosen by us) at which the slope is allowed to change (see Greene, 1997, pp. 388f). We prefer the separate LS-regressions because the spline approach forces the regression line trough the knots making it more dependent on exactly how the division into groups is chosen. As is clear from our results reported in Björklund, Roine and Waldenström (2008), the spline approach is qualitatively the same as the LS approach used here.
} 
whole distribution. ${ }^{22}$ These numbers are in line with previous results for Sweden. When looking at the results across the fathers' income fractiles these indicate slightly higher numbers in the top decile compared to the rest of the distribution, but in particular the elasticities are much higher in the top percentile and extreme in the very top. Literally our result for the top 0.1 group suggests that a 10 percent income differential among high-income fathers is transmitted into a 9.6 percent differential among sons. This should be contrasted against the average transmission in the whole population which is only 2.6 percent. $^{23}$

\section{[Table 2]}

Turning to earnings, we find qualitatively similar patterns but with a weaker increase in the very top. The coefficient for the top 0.1 percentile group is only half as large as it is for income. This difference among income and earnings suggests that it is the capital income component that is strongly inherited at the very top of the distribution.

In the quantile regressions, reported in Table 3, we examine how sensitive sons' incomes and earnings at different levels are to their fathers' incomes and earnings. Although these regressions measure a different aspect of the intergenerational income association, and consequently the respective estimated coefficients cannot be directly compared, the results reveal basically the same non-linear patterns as we saw in the LS-regression analysis. In the case of incomes, there is a somewhat smoother increase in the degree of persistence across generation over the level of sons' incomes. The median regression, Q50, has an intergenerational elasticity of 0.274, which is close to the OLS-estimate in table 2. At the 90th quantile, we observe coefficients of 0.375 and for Q99-coefficient it is 0.455 , which implies that a 10 percent income differential among fathers is related to a 4.6 percent higher income for sons' at the 99th quantile of the distribution. Going even further up the income distribution, we find a coefficient of 0.642 at Q99.9, which is markedly higher than elsewhere in the distribution. The results for earnings, however, are much more stable over the sons' distribution; it is around 0.16 up to Q99 and rises to 0.242 at Q99.9.

\footnotetext{
${ }^{22}$ While this difference between income and earnings might appear as striking, it should be noticed that they also differ in terms of trends in dispersion. Specifically, using information on the ratio of the standard deviation of fathers' and sons' long-run incomes fell by 12.5 percent (0.42/0.48) and the corresponding ratio increased by 14 percent $(0.56 / 0.49)$ for earnings. In other words, the intergenerational correlations (defined as the estimated intergenerational elasticities multiplied by the ratio of the standard deviations) are 0.23 and 0.19 in the two cases.

${ }^{23}$ It is worth pointing out that this is a measure of the expected transmission given that the father is in this top group, rather than a measure of how difficult it is to get to this group. See Hertz (2005) for more on the interpretation of different measures of mobility.
} 
[Table 3]

Our results are summarized in Figures 1 and 2. Besides corroborating previous findings on average Swedish income mobility they also highlight new evidence on notable nonlinearities in this relationship across the distribution of income and earnings. Specifically, we find that while the income associations are relatively weak in the population at large this changes markedly in the top of the distribution. In the absolute top of the distribution we find very strong associations and among fathers in the top 0.1 percentile group income increases are almost completely transmitted to their sons. These non-linear transmission patterns also prevail in the earnings distribution, but to a lesser extent.

[Figures 1 and 2]

Finally, it is illuminating to illustrate the mobility pattern with a transition matrix as well. In contrast to the LS and quantile regression results, which show marginal sensitivity in different segments of the distribution, transition matrixes show global mobility across the whole distribution. In particular they allow us to study the prevalence of large steps and "unusual events" in the income distribution from one generation to the next. Table 4 gives a transition matrix for income with the same group limits as in our regressions. The table reveals that 7.3 percent of the sons of fathers in the P99.9-100 fractile show up in the same fractile for sons. This number is 73 times higher than 0.1 , which would indicate independence between fathers' and sons’ incomes. Forming 19.3 percent of the P99-99.9 group, they are 21 times more likely to appear in this group as compared with random assignment. At the same time as many as 11.9 percent (in contrast to 25 percent with independence) in the group with the richest fathers show up in the P0-25 group of sons. Large upward steps from the bottom half of the distribution to the very top does not exist in our data, but a non-negligible fraction (0.3 percent in contrast to 0.9 percent) move to the P99-99.9 fractile of sons.

The results for earnings are similar to those for total income in most of the distribution, but again there are important differences. In the very top 2.3 percent of the sons of fathers in the P99.9-100 group show up in the corresponding group. This makes them 23 times as likely to appear there when compared to independent assignment. Even though this is a high number it is much lower than the 73 times more likely than under random assignment found when look- 
ing at income. Similarly, 9.3 percent of sons with fathers in the top 0.1 end up in the P99-99.9 group in the son distribution. This makes them about 10 times more likely to be there as compared to random assignment but at the same time it is a significantly lower number than the corresponding 21 for the income results.

\section{[Table 4]}

\section{Robustness analyses}

In our main sample we require positive observations for all years and also require that we have observations for the sons' transmission mechanism variables. The reason is that we want to conduct the mechanism analysis on the same sample as the one for which we have our main results. This procedure, however, creates different samples for earnings and incomes and also means that we loose a relatively large number of observations. Clearly we want to make sure that our results are not sensitive to this. ${ }^{24}$

We start by asking whether the difference in results for income and earnings is in any way driven by the fact that the estimations in Tables 2 and 3 were done on two different samples. In rows $1 \mathrm{a}$ and $1 \mathrm{~b}$ of Table 5 (piecewise linear) and Table 6 (quantile regressions), we report estimates for the same models as in Table 2 and 3, but requiring that fathers had both positive incomes and positive earnings each year 1974-1979 (giving us the same sample when estimating earnings and incomes, respectively). The results are similar to those in our main specification, suggesting that the differences in results between income and earnings are not due to the differences in the samples.

Next we check how our results change if we include observations with zero reported income or earnings (in one or several years). We treat these zeros as missing values, i.e. average income over the years for which we have positive reported values, which is approximately the same as interpolating over the zeros. We do so because we think that for the most part they are likely to reflect some form of reporting problem or mistake. While it may be the case that individuals that have studied the whole year, been unemployed the whole year or left the labor force (for retirement or something else) for the whole year, have zero income from work it is in most cases unlikely that they would not collect some taxable social transfers or capital in-

\footnotetext{
${ }^{24}$ Table A1 explains how our sample changes depending on the various requirements we introduce.
} 
come. This would seem especially strange in the top of the distribution. In addition, in cases where the tax declaration process is not completed or if there is a dispute between the individual and the tax authorities, this is also recorded as a zero. This situation in turn seems more likely in the top of the distribution. In rows 2a and 2b of Table 5 (piecewise linear) and Table 6 (quantile regressions), we report estimates when using the same requirements as in our main analysis but now also including observations where zeros are present. The main difference that we find is that the coefficients for income become slightly lower while the earnings coefficients go up in the top. However, the overall picture of transmission being stronger in the top, and more so for income than for earnings, remains. ${ }^{25}$

Finally we consider the case where we drop the condition that we require observations of the sons' transmission mechanism variables. This gives us significantly larger samples. In rows 3a and 3b of Table 5 (piecewise linear) and Table 6 (quantile regressions), we show the results when making the same requirements as in our main regressions but also including all observations with positive values all years but for which we do not have the transmission mechanism data. In rows $4 \mathrm{a}$ and $4 \mathrm{~b}$ we report the results when also allowing zero observations to be present. The basic results are again similar to our main results, with the exception of the top earnings piecewise linear regression coefficients in 3b which are lower than in the other specifications.

\section{[Table 5 and 6]}

\section{Transmission channels}

Establishing the high degree of income transmission from father to son in the top of the distribution obviously raises questions about its sources. Why is it that the intergenerational association is so strong in the top? What is it that sons of income rich fathers inherit that translates into such a strong income relation? Even though one may interpret the differences between the results for earnings and total income as indicative of the importance of capital, questions

\footnotetext{
${ }^{25}$ We have also checked what happens when we treat zeros as being correct and include these values when averaging. This results in coefficients where the earnings transmission is even stronger in the piecewise linear regressions (but not in the quantile regressions). The general non-linear pattern remains. Treating zeros as correct also introduces the problem of using the log of averages or the average of logs when calculating the long run income. We have tried different specifications and these all show qualitatively similar results (available from the authors upon request).
} 
remain and there is no general method that can be used to answer them. ${ }^{26}$ The basic problem is that just about every plausible factor can work directly as well as indirectly through a number of different channels. Assets, education, intelligence, and social skills can all have effects on each other as well as directly on income and they can be transmitted from one generation to the next through various processes.

A seemingly straightforward approach would have been to estimate a recursive system of equations in which parental income is allowed to have an indirect impact on income-enhancing variables (such as IQ) in one equation, and a direct effect (net of IQ) in another equation. With estimates from such equations the total "effect" could be disentangled into direct and indirect ones. However, it is well known that such a system of equations requires strong identifying assumptions. In particular the error terms in the equations must be uncorrelated, which typically seems a strong assumption. Here we limit ourselves to looking for suggestive evidence about variables that can, and cannot, account for the dramatic discontinuity in income transmission in the very top of the fathers' income distribution. Our approach is to simply change the left-hand variable in our basic model, i.e., son's income, to be other son outcomes that capture possible channels of transmission such as IQ, non-cognitive skills, education and wealth. If the association between these outcomes and father income is positive, this indicates a potential channel of transmission. If, on the other hand, there is no association, or if it turns out to be negative, it seems difficult to construct a model where this particular factor plays a role in explaining the positive income association across generations.

We use six different measures of four plausible transmission mechanisms: IQ, non-cognitive skills, education, and three different measures of wealth, namely net worth, financial assets, and taxable wealth. For the IQ, non-cognitive skills and education measures we also run separate regressions using dummy variables for the highest level of achievement since we are looking for variables that can explain income and earnings at the very top.

Table 7 reports descriptive statistics by fathers' income and earnings fractiles. These statistics themselves are suggestive about which mechanisms are important in the top and which are not. In the income sample, IQ, non-cognitive skills and education increase over the distribution until the very top where the variables actually fall a bit. In contrast, all indicators of

\footnotetext{
${ }^{26}$ Goldberger (1989) points to the general difficulty of disentangling various processes behind intergenerational transmissions. Solon (1999) includes a comprehensive discussion of this.
} 
wealth rise markedly in the top and particularly when moving from P99-99.9 to P99.9-100. In the earnings sample, the three skill measures are either stable or declining slightly in the very top whereas the wealth indicators again increase markedly. The level of wealth in the top of the fathers' earnings distribution is, however, clearly lower than in the top of the income distribution. $^{27}$

\section{[Table 7]}

In Table 8 and 9 we turn to the piecewise linear income and earnings regressions, which are estimated within the fractiles of fathers' income and earnings. In addition to estimates for the raw mediating variables, we report estimates for dummy variables for the highest level of IQ, non-cognitive skills and education, as well as the log of the wealth variables. ${ }^{28}$ The results from the descriptive tables hold up even when we look at transmission within the top income fractiles. Whereas all skill variables are positive at least up through P95-99, they are always insignificant (often even with a negative point estimate) in the very top. Thus, we find it most unlikely that skill is an important mediating variable for the strong income and earnings transmission in the very top. Wealth, on the other hand, looks very different in the top of the distribution. For income, the coefficients are always positive and clearly significantly different from zero except when taxable wealth in measured in absolute terms when the t-ratio is only 1.28 .

We summarize the results for income in Figure 3. For earnings, the coefficients are also positive but not always significantly so and the logged variables (which express elasticities) are lower than for income. We summarize the results for earnings in Figure 4.

[Table 8 and 9; Figure 3 and 4]

\footnotetext{
${ }^{27}$ The strong earnings transmission in the top also suggests that there may be labor market channels that we do not consider here. Corak and Piraino (2011) find interesting strong transmission of employees in the top that are likely to be part of explaining non-linearities in earnings transmission.

${ }^{28}$ High IQ, non-cognitive skills and education are dummy variables equal to one when sons are approximately in the top five percentiles in the respective distributions.
} 


\section{Concluding discussion}

Our results have implications for the study of intergenerational mobility in general as well as for understanding mobility in Sweden. Analogously to what has previously been established in the top income literature, we conclude that it is crucial to study even small fractions within the top of the distribution to get a more complete picture of intergenerational mobility. Discussing "the top" as consisting of the top 20, top 10, or even the top 5 percent, runs the risk of missing important aspects. Indeed, our most striking results do not appear until within the top percentile. Furthermore, as is also suggested by the top income literature, it is important to separate different sources of income, in particular to distinguish between earnings and income including capital income. Both the degree of transmission as well as the channels is likely to be different depending on source of income.

With respect to mobility in Sweden, our main finding is that intergenerational transmission of income is remarkably strong in the very top of the distribution and that the most likely mechanism for this is inherited wealth. However, our results also confirm what previous work has shown, namely that transmission is relatively low in general. A possible interpretation of this, alluded to in the title of the paper, is that family background plays a relatively small role in determining people's economic outcomes in general, but at the same time "capitalist dynasties” in the very top of the distribution persist. Interestingly, this picture is well in line with an often-heard characterization of Sweden as a society that has tried to combine high egalitarian ambitions with good investment incentives for large capital holders.

In an international comparative perspective, our results give rise to two alternative interpretations. Either the combination of high overall earnings mobility and extremely high income transmission in the top is a unique feature of the extensive welfare state, perhaps even a consequence of a particular "Nordic model”, or, alternatively, income persistence in the top is just as high, or even higher, in societies like the U.S. where overall mobility is lower than in Sweden. Determining which is right requires studies of top income mobility for other countries. 


\section{References}

ALESINA, A., GLAESER, E. and SACERDOTE, B. (2001), "Why Doesn't the United States Have a European-Style Welfare State?” Brookings Papers on Economic Activity, 2, 1-69.

ALESINA, A. and GLAESER, E. (2004), Fighting Poverty in the U.S. and Europe: A World of Difference (Oxford: Oxford University Press).

ATKINSON, A. B. (2004), “Top Incomes in the UK over the Twentieth Century”, Journal of the Royal Statistical Society, Series A, 168, 325-343.

ATKINSON, A. B. and PIKETTY, T. (eds.) (2007), Top Incomes over the Twentieth Century - A Contrast between European and English-Speaking Countries (Oxford: Oxford University Press).

ATKINSON, A. B. and PIKETTY, T. (eds.) (2010), Top Incomes - A Global Perspective (Oxford: Oxford University Press).

BJÖRKLUND, A., ROINE, J. and WALDENSTRÖM, D. (2008), "Intergenerational Top Income Mobility in Sweden: A Combination of Equal Opportunity and Capitalistic Dynasties”, (Discussion Paper No. 3801, IZA).

BJÖRKLUND, A. and JÄNTTI, M. (2009), "Intergenerational Income Mobility and the Role of Family Background”, in Nolan, B., Salverda, W. and Smeeding, T. (eds.), Oxford Handbook of Economic Inequality (Oxford: Oxford University Press).

BLACK S. E. and DEVEREUX, P. J. (2010), "Recent Developments in Intergenerational Mobility”, (Working Paper No. 15889, National Bureau of Economic Research).

BRATSBERG, B., RØED, K., RAAUM, O., NAYLOR, R., JÄNTTI, M., ERIKSSON, T. and ÖSTERBACKA, E. (2007), "Nonlinearities in Intergenerational Earnings Mobility: Consequences for Cross-Country Comparisons”, Economic Journal, 117, C72-C92.

BÖHLMARK, A. and LINDQUIST, M. (2006), "Life-Cycle Variations in the Association between Current and Lifetime Income: Replication and Extension for Sweden”, Journal of Labor Economics, 24, 879-900.

CESARINI, D. (2010), "Family influences on Productive Skills, Human Capital and Lifecycle Income”, (Mimeo, New York University).

CHADWICK, L and SOLON, G. (2002), "Intergenerational Income Mobility Among Daughters”, American Economic Review, 92, 335-344.

CORAK, M. (2006), "Do Poor Children Become Poor Adults? Lessons from a Cross-Country Comparison of Generational Earnings Mobility”, Research on Economic Inequality, 13, 143-188.

CORAK, M. and HEISZ, A. (1999), “The Intergenerational Earnings and Income Mobility of Canadian Men: Evidence from Longitudinal Income Tax Data”, Journal of Human Resources, 34, 504-533.

CORAK, M. and PIRAINO, P. (2010), “The Intergenerational Transmission of Employers”, Journal of Labor Economics, forthcoming.

COUCH, K. A., LIllard, D. R. (2004), "Non-linear patterns in Germany and the United States”, in Corak, M. (ed) Generational Income Mobility in North America and Europe, (Cambridge: Cambridge University Press). 
EDLUND, L. and KOPCZUK, W. (2009), "Women, Wealth and Mobility”, American Economic Review, 99, 146-178.

EIDE, E. R. and SHOWALTER, M. H. (1999), "Factors Affecting the Transmission of Earnings across Generations: A Quantile Regression Approach”, Journal of Human Resources, 34, 253-267.

FINNIE, R. and IRVINE, I. (2006), "Mobility and Gender at the Top Tail of the Earnings Distribution”, Economic and Social Review, 37, 149-173.

FONG, C. (2001), “Social Preferences, Self-Interest, and the Demand for Redistribution”, Journal of Public Economics, 82, 225-246.

GOLDBERGER, A. S. (1989), "Economic and Mechanical Models of Intergenerational Transmission”, American Economic Review, 79, 505-513.

GRAWE N. D. and MULLIGAN, C. B. (2002), “Economic Interpretations of Intergenerational Correlations”, Journal of Economic Perspectives, 16, 45-58.

GRAWE, N. (2004), "Reconsidering the Use of Nonlinearities in Intergenerational Earnings Mobility as a Test for Credit Constraints”. Journal of Human Resources, 39, 813-827.

GREENE, W. H. (1997), Econometric Analysis, 3rd Edition, (Upper Saddle River, N.J.: Prentice Hall).

HERTZ, T. (2005), "Rags, Riches, and Race: The Intergenerational Economic Mobility of Black and White Families in the United States", in Bowles, S., Gintis, H. and Osborne Growes, M. (eds.). Unequal Chances, (Princeton, N.J.: Princeton University Press).

JENCKS, C. and Tach, L. (2006), "Would Equal Opportunity Mean More Mobility?”, in Morgan, S. L., Grusky, D. B., Fields, G. S. (eds.), Mobility and Inequality, (Stanford, CA: Stanford University Press).

JÄNTTI, M., BRATSBERG, B., ROED, K., RAAUM, O., NAYLOR, R., ÖSTERBACKA, E., BJÖRKLUND, A. and ERIKSSON, T. (2006), "American Exceptionalism in a New Light: A Comparison of Intergenerational Earnings Mobility in the Nordic Countries", (Discussion Paper No. 1938, IZA).

KOENKER, R. and HALLOCK, K. F. (2001), “Quantile Regression”, Journal of Economic Perspectives, 15, 143-156.

KOPZCUK, W. and SAEZ, E. (2004), “Top Wealth Shares in the United States, 1916-2000: Evidence from Estate Tax Returns”, National Tax Journal, 57, 445-487.

KOPZCUK, W., SAEZ, E. and SONG, J. (2010), "Earnings Inequality and Mobility in the United States: Evidence from Social Security Data since 1937”, Quarterly Journal of Economics, 125, 91-128.

LINDQUIST, E, and WESTMAN, R. (2010), “The Labor Market Returns to Cognitive and Noncognitive Ability: Evidence from the Swedish Enlistment”, American Economic Journal: Applied Economics, forthcoming.

PIKETTY, T. (2001), Les hauts revenus en France au 20ème siècle (Paris: Grasset).

PIKETTY, T. and SAEZ, E. (2003), "Income Inequality in the United States, 1913-1998”, Quarterly Journal of Economics, 118, 1-39.

ROINE, J. and WALDENSTRÖM, D. (2008), “The Evolution of Top Incomes in an Egalitarian Society: Sweden, 1903-2004”, Journal of Public Economics, 92, 366-387. 
ROINE, J. and WALDENSTRÖM, D. (2009), "Wealth Concentration over the Path of Development: Sweden, 1873-2006”, Scandinavian Journal of Economics, 111, 151-187.

ROINE, J. and WALDENSTRÖM, D. (2010), “Top incomes in Sweden”, in A. Atkinson, and T. Piketty (eds.) Top Incomes - A Global Perspective, (Oxford, Oxford University Press).

SAEZ, E. and VEALL, M. (2005), "The Evolution of High Incomes in Northern America: Lessons from Canadian Evidence”, American Economic Review, 95, 831-849.

SOLON, G. (1999), "Intergenerational Mobility in the Labor Market,” in Ashenfelter, O. and Card, D. (eds.) Handbook of Labor Economics, Volume 3A. (Amsterdam, Elsevier Science). 
Table 1: Descriptive statistics for main income and earnings samples.

\begin{tabular}{llrrrrrrrrrr}
\hline \hline Variable & Type & Mean & S.D. & Min & P10 & P50 & P90 & P95 & P99 & P99.9 & Max \\
\hline Fathers: & & & & & & & & & & & \\
\hline \multirow{2}{*}{ Age in 1979 } & Inc. & 45.1 & 7.2 & 27 & 36 & 44 & 55 & 58 & 64 & 73 & 86 \\
& Earn. & 44.7 & 6.8 & 28 & 36 & 44 & 54 & 57 & 62 & 69 & 81 \\
\hline \multirow{2}{*}{ Income in 1979 } & Inc. & 252 & 140 & & 137 & 227 & 382 & 470 & 751 & 1,313 & 12,263 \\
& Earn. & 258 & 127 & & 157 & 232 & 386 & 472 & 740 & 1,213 & 4,573 \\
\hline Average income & Inc. & 254 & 137 & 3 & 151 & 226 & 379 & 467 & 756 & 1,280 & 13,950 \\
1974-1979 & Earn. & 256 & 122 & 1 & 160 & 229 & 382 & 466 & 740 & 1,157 & 4,467 \\
\hline Average log & Inc. & 12.34 & 0.42 & 7.74 & 11.89 & 12.32 & 12.84 & 13.04 & 13.52 & 14.02 & 16.39 \\
income 1974-1979 & Earn. & 12.32 & 0.56 & 6.88 & 11.94 & 12.33 & 12.85 & 13.04 & 13.50 & 13.95 & 15.24 \\
\hline
\end{tabular}

Sons:

\begin{tabular}{|c|c|c|c|c|c|c|c|c|c|c|c|}
\hline \multirow{2}{*}{ Age in 2005} & Inc. & 40.9 & 2.0 & 38 & 38 & 41 & 44 & 44 & 45 & 45 & 45 \\
\hline & Earn. & 40.9 & 2.0 & 38 & 38 & 41 & 44 & 44 & 45 & 45 & 45 \\
\hline \multirow{2}{*}{ Income in 2005} & Inc. & 357 & 431 & & 180 & 299 & 546 & 689 & 1,292 & 4,592 & 45,223 \\
\hline & Earn. & 351 & 224 & & 187 & 309 & 548 & 675 & 1,093 & 2,834 & 10,802 \\
\hline \multirow{2}{*}{$\begin{array}{l}\text { Average income } \\
\text { 1996-2005 }\end{array}$} & Inc. & 304 & 283 & & 173 & 265 & 452 & 553 & 920 & 3,099 & 43,346 \\
\hline & Earn. & 302 & 165 & 3 & 177 & 272 & 453 & 540 & 806 & 1,981 & 13,051 \\
\hline \multirow{2}{*}{$\begin{array}{l}\text { Average log } \\
\text { income 1996-2005 }\end{array}$} & Inc. & 12.46 & 0.48 & 3.13 & 11.98 & 12.47 & 12.98 & 13.17 & 13.58 & 14.48 & 17.50 \\
\hline & Earn. & 12.46 & 0.49 & 5.94 & 11.91 & 12.49 & 12.99 & 13.17 & 13.54 & 14.32 & 16.10 \\
\hline \multirow{2}{*}{ IQ } & Inc. & 5.2 & 1.9 & 1 & 3 & 5 & 8 & 8 & 9 & 9 & 9 \\
\hline & Earn. & 5.3 & 1.9 & 1 & 3 & 5 & 8 & 8 & 9 & 9 & 9 \\
\hline \multirow{2}{*}{$\begin{array}{l}\text { Non-cognitive } \\
\text { skills }\end{array}$} & Inc. & 5.2 & 1.6 & 1 & 3 & 5 & 7 & 8 & 9 & 9 & 9 \\
\hline & Earn. & 5.3 & 1.6 & 1 & 3 & 5 & 7 & 8 & 9 & 9 & 9 \\
\hline \multirow{2}{*}{ Education years } & Inc. & 12.0 & 2.1 & 7 & 9 & 11 & 15 & 16 & 18 & 20 & 20 \\
\hline & Earn. & 12.1 & 2.1 & 7 & 9 & 11 & 15 & 16 & 20 & 20 & 20 \\
\hline \multirow{2}{*}{ Net worth } & Inc. & 378 & 2,596 & $-24,371$ & -136 & 120 & 1,023 & 1,643 & 3,938 & 12,500 & 734,300 \\
\hline & Earn. & 360 & 1,163 & $-24,371$ & -130 & 133 & 993 & 1,552 & 3,600 & 12,000 & 78,190 \\
\hline \multirow{2}{*}{ Financial assets } & Inc. & 145 & 2,361 & 0 & 0 & 27 & 314 & 558 & 1,482 & 6,433 & 746,400 \\
\hline & Earn. & 137 & 618 & 0 & 0 & 30 & 315 & 553 & 1,479 & 5,917 & 64,115 \\
\hline \multirow{2}{*}{ Taxable wealth } & Inc. & 46 & 546 & $-1,991$ & 0 & 0 & 0 & 91 & 1,202 & 5,178 & 85,112 \\
\hline & Earn. & 44 & 509 & $-1,908$ & 0 & 0 & 0 & 91 & 1,202 & 4,826 & 85,112 \\
\hline
\end{tabular}

Note: The income (earnings) sample consists of father-son pairs with positive income (earnings) all years. Incomes, earnings and all wealth measures are in thousand 2005 SEK. IQ and non-cognitive skills are in Stanine scale. Observations are 108,277 (incomes) and 85,848 (earnings). Fathers are observed during 1974-1979 and sons in 1996-2005 (except for Net worth and Financial assets which are averages based on the period 19992005). See text for further details. 
Table 2: Main Results. Piecewise linear regressions across fathers’ fractiles

\begin{tabular}{|c|c|c|c|c|c|c|}
\hline & \multirow{2}{*}{$\begin{array}{c}\text { Global } \\
\text { P0-100 }\end{array}$} & \multicolumn{5}{|c|}{ Piecewise linear } \\
\hline & & P0-90 & P90-95 & P95-99 & P99-99.9 & P99.9-100 \\
\hline \multicolumn{7}{|l|}{ Incomes: } \\
\hline Father income & $\begin{array}{c}0.260 \\
(0.004)\end{array}$ & $\begin{array}{c}0.220 \\
(0.005)\end{array}$ & $\begin{array}{c}0.278 \\
(0.133)\end{array}$ & $\begin{array}{c}0.244 \\
(0.070)\end{array}$ & $\begin{array}{c}0.606 \\
(0.174)\end{array}$ & $\begin{array}{c}0.959 \\
(0.242)\end{array}$ \\
\hline $\operatorname{Pr}\left(\hat{\beta}=\hat{\beta}^{O L S}\right)$ & & [0.000] & [0.892] & [0.820] & {$[0.047]$} & [0.004] \\
\hline $\mathrm{N}$ & 108,277 & 97,449 & 5,414 & 4,331 & 974 & 109 \\
\hline \multicolumn{7}{|l|}{ Earnings: } \\
\hline Father earnings & $\begin{array}{c}0.168 \\
(0.004)\end{array}$ & $\begin{array}{c}0.125 \\
(0.004)\end{array}$ & $\begin{array}{c}0.335 \\
(0.152)\end{array}$ & $\begin{array}{c}0.187 \\
(0.072)\end{array}$ & $\begin{array}{c}0.558 \\
(0.200)\end{array}$ & $\begin{array}{c}0.507 \\
(0.173)\end{array}$ \\
\hline $\operatorname{Pr}\left(\hat{\beta}=\hat{\beta}^{O L S}\right)$ & & {$[0.000]$} & {$[0.272]$} & {$[0.789]$} & {$[0.051]$} & {$[0.050]$} \\
\hline $\mathrm{N}$ & 85,848 & 77,263 & 4,292 & 3,434 & 773 & 86 \\
\hline
\end{tabular}

Note: Results based on estimating equation (1). Robust standard errors are in parenthesis. P-values from test of equality with the OLS coefficient are in brackets. Constant term suppressed.

Table 3: Quantile regressions across sons’ conditional fractiles

\begin{tabular}{lccccc}
\hline \hline & Median $(\mathrm{Q} 50)$ & $\mathrm{Q} 90$ & $\mathrm{Q} 95$ & $\mathrm{Q} 99$ & $\mathrm{Q} 99.9$ \\
\hline Father income & 0.232 & 0.328 & 0.334 & 0.380 & 0.536 \\
& $(0.003)$ & $(0.005)$ & $(0.007)$ & $(0.014)$ & $(0.035)$ \\
$\operatorname{Pr}\left(\hat{\beta}=\hat{\beta}^{Q 50}\right)$ & & {$[0.000]$} & {$[0.000]$} & {$[0.000]$} & {$[0.000]$} \\
& & & & & \\
Father earnings & 0.160 & 0.168 & 0.157 & 0.158 & 0.242 \\
& $(0.004)$ & $(0.003)$ & $(0.005)$ & $(0.007)$ & $(0.019)$ \\
$\operatorname{Pr}\left(\hat{\beta}=\hat{\beta}^{Q 50}\right)$ & & {$[0.026]$} & {$[0.591]$} & {$[0.823]$} & {$[0.000]$} \\
\hline \hline
\end{tabular}

Note: Bootstrapped standard errors (using 100 replications) in parenthesis. P-values from $\chi^{2}$-test of coefficient equality with the median $(Q 50)$ regression coefficient are in brackets. Sample sizes are 108,277 for incomes and 85,848 for earnings. 
Table 4: Transition matrices

a) Incomes

Son's income fractile

P0-25 P25-50 P50-75 P75-90 P90-95 P95-99 $\quad$ P99-99.9 P99.9-100

\begin{tabular}{|c|c|c|c|c|c|c|c|c|c|}
\hline \multicolumn{10}{|c|}{$\begin{array}{l}\text { Father's income } \\
\text { fractile: }\end{array}$} \\
\hline P0-25 & 33.2 & 29.3 & 22.9 & 10.1 & 2.6 & 1.5 & 0.3 & 0.0 & 100.0 \\
\hline P25-50 & 26.0 & 29.8 & 27.2 & 11.9 & 3.0 & 1.8 & 0.3 & 0.0 & 100.0 \\
\hline P50-75 & 22.4 & 25.0 & 28.3 & 16.0 & 4.5 & 3.2 & 0.6 & 0.0 & 100.0 \\
\hline P75-90 & 19.6 & 18.6 & 24.2 & 21.1 & 8.2 & 6.9 & 1.3 & 0.2 & 100.0 \\
\hline P90-95 & 16.8 & 13.2 & 20.5 & 24.5 & 11.5 & 10.4 & 2.8 & 0.4 & 100.0 \\
\hline P95-99 & 16.4 & 11.3 & 15.8 & 23.4 & 13.3 & 14.9 & 4.5 & 0.4 & 100.0 \\
\hline P99-99.9 & 16.3 & 7.4 & 11.3 & 19.8 & 15.3 & 21.7 & 6.4 & 1.8 & 100.0 \\
\hline P99.9-100 & 11.9 & 3.7 & 8.3 & 11.9 & 10.1 & 27.5 & 19.3 & 7.3 & 100.0 \\
\hline
\end{tabular}

b) Earnings

Son's earnings fractile

$\begin{array}{llllllll}\text { P0-25 P25-50 P50-75 } & \text { P75-90 } & \text { P90-95 } & \text { P95-99 } & \text { P99-99.9 P99.9-100 }\end{array}$

Father's earnings

fractile:

\begin{tabular}{lccccccccc} 
P0-25 & 32.5 & 29.7 & 23.0 & 10.1 & 2.7 & 1.7 & 0.3 & 0.0 & 100.0 \\
P25-50 & 26.5 & 29.8 & 26.9 & 11.7 & 2.9 & 1.8 & 0.3 & 0.0 & 100.0 \\
P50-75 & 22.8 & 24.6 & 28.0 & 15.8 & 4.7 & 3.3 & 0.6 & 0.1 & 100.0 \\
P75-90 & 19.3 & 18.3 & 24.4 & 21.4 & 8.4 & 6.8 & 1.4 & 0.2 & 100.0 \\
P90-95 & 17.2 & 14.0 & 21.7 & 23.0 & 10.4 & 10.3 & 2.9 & 0.4 & 100.0 \\
P95-99 & 15.7 & 11.4 & 16.3 & 25.6 & 12.7 & 13.9 & 4.0 & 0.4 & 100.0 \\
P99-99.9 & 15.8 & 7.1 & 13.6 & 21.7 & 14.5 & 19.1 & 7.0 & 1.2 & 100.0 \\
P99.9-100 & 10.5 & 4.7 & 12.8 & 17.4 & 12.8 & 30.2 & 9.3 & 2.3 & 100.0 \\
\hline \hline
\end{tabular}


Table 5: Robustness analysis: Piecewise linear regressions (incomes and earnings)

\begin{tabular}{|c|c|c|c|c|c|c|}
\hline & \multirow{2}{*}{$\begin{array}{c}\text { Global } \\
\text { P0-100 }\end{array}$} & \multicolumn{5}{|c|}{ Piecewise linear } \\
\hline & & P0-90 & P90-95 & P95-99 & P99-99.9 & P99.9-100 \\
\hline \multicolumn{7}{|c|}{ Alt. sample 1: Main sample, but require both positive income and earnings all years } \\
\hline \multirow[t]{2}{*}{ 1a. Father income } & 0.293 & 0.249 & 0.341 & 0.262 & 0.582 & 0.878 \\
\hline & $(0.004)$ & $(0.006)$ & $(0.129)$ & $(0.068)$ & $(0.162)$ & $(0.251)$ \\
\hline $\operatorname{Pr}\left(\hat{\beta}=\hat{\beta}^{\text {Global }}\right)$ & & {$[0.000]$} & {$[0.711]$} & [0.652] & [0.074] & {$[0.020]$} \\
\hline $\mathrm{N}$ & 85,753 & 77,177 & 4,288 & 3,430 & 772 & 86 \\
\hline \multirow[t]{2}{*}{ 1b. Father earnings } & 0.168 & 0.125 & 0.334 & 0.189 & 0.526 & 0.507 \\
\hline & $(0.004)$ & $(0.004)$ & $(0.153)$ & $(0.072)$ & (0.199) & $(0.173)$ \\
\hline $\operatorname{Pr}\left(\hat{\beta}=\hat{\beta}^{\text {Global }}\right)$ & & {$[0.000]$} & {$[0.275]$} & {$[0.762]$} & {$[0.072]$} & {$[0.050]$} \\
\hline $\mathrm{N}$ & 85,753 & 77,177 & 4,288 & 3,430 & 772 & 86 \\
\hline \multicolumn{7}{|c|}{ Alt. sample 2: Main sample, but also include observations with zeros (although exclude zeros from averages) } \\
\hline \multirow[t]{2}{*}{ 2a. Father income } & 0.248 & 0.220 & 0.168 & 0.154 & 0.474 & 0.848 \\
\hline & $(0.005)$ & $(0.006)$ & $(0.154)$ & $(0.087)$ & $(0.275)$ & $(0.212)$ \\
\hline $\operatorname{Pr}\left(\hat{\beta}=\hat{\beta}^{\text {Global }}\right)$ & & {$[0.000]$} & [0.599] & [0.278] & [0.412] & [0.005] \\
\hline $\mathrm{N}$ & 117,837 & 106,050 & 5,894 & 4,713 & 1,062 & 118 \\
\hline \multirow{2}{*}{ 2b. Father earnings } & 0.132 & 0.099 & 0.280 & 0.167 & 0.696 & 0.831 \\
\hline & $(0.003)$ & $(0.003)$ & $(0.162)$ & $(0.084)$ & (0.209) & $(0.201)$ \\
\hline \multirow[t]{2}{*}{$\operatorname{Pr}\left(\hat{\beta}=\hat{\beta}^{\text {Global }}\right)$} & & [0.000] & [0.360] & [0.676] & [0.007] & [0.001] \\
\hline & 116,366 & 104,720 & 5,821 & 4,658 & 1,049 & 118 \\
\hline \multicolumn{7}{|c|}{ Alt. sample 3: Main sample, but also include observations where sons lack any of the transmission variables } \\
\hline \multirow[t]{2}{*}{ 3a. Father income } & 0.262 & 0.225 & 0.245 & 0.220 & 0.381 & 0.752 \\
\hline & $(0.004)$ & $(0.005)$ & $(0.122)$ & $(0.065)$ & $(0.160)$ & $(0.247)$ \\
\hline $\operatorname{Pr}\left(\hat{\beta}=\hat{\beta}^{\text {Global }}\right)$ & & [0.000] & [0.887] & [0.511] & [0.455] & [0.048] \\
\hline $\mathrm{N}$ & 130,047 & 117,042 & 6,502 & 5,202 & 1,170 & 131 \\
\hline \multirow[t]{2}{*}{ 3b. Father earnings } & 0.169 & 0.126 & 0.269 & 0.152 & 0.372 & 0.251 \\
\hline & $(0.003)$ & $(0.004)$ & $(0.138)$ & $(0.070)$ & $(0.176)$ & (0.359) \\
\hline $\operatorname{Pr}\left(\hat{\beta}=\hat{\beta}^{\text {Global }}\right)$ & & [0.000] & [0.468] & [0.809] & [0.249] & [0.818] \\
\hline $\mathrm{N}$ & 101,635 & 91,471 & 5,082 & 4,065 & 915 & 102 \\
\hline \multicolumn{7}{|c|}{ Alt. sample 4: Same as alt. sample 3, but include observations with zeros (but exclude zeros from averages) } \\
\hline \multirow[t]{2}{*}{ 4a. Father income } & 0.251 & 0.227 & 0.122 & 0.128 & 0.404 & 0.734 \\
\hline & $(0.005)$ & $(0.005)$ & $(0.141)$ & $(0.079)$ & $(0.235)$ & $(0.212)$ \\
\hline $\operatorname{Pr}\left(\hat{\beta}=\hat{\beta}^{\text {Global }}\right)$ & & [0.001] & {$[0.360]$} & [0.121] & [0.515] & [0.023] \\
\hline $\mathrm{N}$ & 142,046 & 127,834 & 7,106 & 5,683 & 1,280 & 143 \\
\hline \multirow[t]{2}{*}{ 4b. Father earnings } & 0.134 & 0.102 & 0.245 & 0.087 & 0.530 & 0.569 \\
\hline & $(0.003)$ & $(0.003)$ & $(0.152)$ & $(0.080)$ & (0.191) & $(0.273)$ \\
\hline $\operatorname{Pr}\left(\hat{\beta}=\hat{\beta}^{\text {Global }}\right)$ & & [0.000] & [0.466] & [0.554] & [0.039] & [0.112] \\
\hline $\mathrm{N}$ & 139,210 & 125,257 & 6,966 & 5,587 & 1,261 & 139 \\
\hline
\end{tabular}

Note: Robust standard errors are in parenthesis. P-values from a test of coefficient equality with the OLS coefficient are in brackets. 
Table 6: Robustness analysis: Quantile regressions (incomes and earnings)

\begin{tabular}{|c|c|c|c|c|c|}
\hline & Q50 & Q90 & Q95 & Q99 & Q99.9 \\
\hline \multicolumn{6}{|c|}{ Alt. sample 1: Positive income and earnings all years + all sons' transmisson variables } \\
\hline \multirow[t]{2}{*}{ 1a. Father income } & 0.274 & 0.375 & 0.384 & 0.455 & 0.642 \\
\hline & $(0.005)$ & $(0.007)$ & $(0.009)$ & $(0.021)$ & $(0.041)$ \\
\hline $\operatorname{Pr}\left(\hat{\beta}=\hat{\beta}^{Q 50}\right)$ & & {$[0.000]$} & {$[0.000]$} & {$[0.000]$} & {$[0.000]$} \\
\hline \multirow[t]{2}{*}{ 1b.Father earnings } & 0.159 & 0.168 & 0.157 & 0.158 & 0.242 \\
\hline & $(0.004)$ & $(0.003)$ & $(0.005)$ & $(0.007)$ & $(0.014)$ \\
\hline \multicolumn{2}{|l|}{$\operatorname{Pr}\left(\hat{\beta}=\hat{\beta}^{Q 50}\right)$} & [0.026] & [0.591] & [0.823] & [0.000] \\
\hline \multicolumn{6}{|c|}{ Alt. sample 2: Main sample +observations with zeros, but treat the zero years as missing } \\
\hline \multirow[t]{2}{*}{ 2a. Father income } & 0.214 & 0.275 & 0.259 & 0.263 & 0.312 \\
\hline & $(0.004)$ & $(0.005)$ & $(0.007)$ & $(0.01)$ & $(0.022)$ \\
\hline $\operatorname{Pr}\left(\hat{\beta}=\hat{\beta}^{Q 50}\right)$ & & {$[0.000]$} & {$[0.000]$} & {$[0.000]$} & [0.000] \\
\hline \multirow[t]{2}{*}{ 2b. Father earnings } & 0.106 & 0.117 & 0.116 & 0.119 & 0.165 \\
\hline & $(0.003)$ & $(0.002)$ & $(0.002)$ & $(0.006)$ & $(0.017)$ \\
\hline \multicolumn{2}{|l|}{$\operatorname{Pr}\left(\hat{\beta}=\hat{\beta}^{Q 50}\right)$} & {$[0.001]$} & [0.004] & [0.049] & [0.001] \\
\hline \multicolumn{6}{|c|}{ Alt. sample 3: Same requirements as for the main sample but no requirement on transmission variables. } \\
\hline \multirow[t]{2}{*}{ 3a. Father income } & 0.233 & 0.331 & 0.338 & 0.381 & 0.531 \\
\hline & $(0.003)$ & $(0.004)$ & $(0.005)$ & $(0.006)$ & $(0.011)$ \\
\hline $\operatorname{Pr}\left(\hat{\beta}=\hat{\beta}^{Q 50}\right)$ & & {$[0.000]$} & [0.000] & [0.000] & {$[0.000]$} \\
\hline \multirow[t]{2}{*}{ 3b. Father earnings } & 0.158 & 0.169 & 0.16 & 0.164 & 0.252 \\
\hline & $(0.003)$ & $(0.004)$ & $(0.003)$ & $(0.005)$ & $(0.006)$ \\
\hline $\operatorname{Pr}\left(\hat{\beta}=\hat{\beta}^{Q 50}\right)$ & & [0.059] & [0.755] & [0.303] & {$[0.000]$} \\
\hline
\end{tabular}

Alt. sample 4: Same as sample 3, but include observations with zeros (but exclude zeros from averages)

$\begin{array}{cccccc}\text { 4a. Father income } & 0.218 & 0.279 & 0.267 & 0.268 & 0.312 \\ & (0.003) & (0.003) & (0.005) & (0.007) & (0.012) \\ \operatorname{Pr}\left(\hat{\beta}=\hat{\beta}^{Q 50}\right) & & {[0.000]} & {[0.000]} & {[0.000]} & {[0.000]}\end{array}$

$\begin{array}{cccccc}\text { 4b. Father earnings } & 0.109 & 0.118 & 0.117 & 0.12 & 0.165 \\ & (0.003) & (0.002) & (0.002) & (0.002) & (0.005) \\ \operatorname{Pr}\left(\hat{\beta}=\hat{\beta}^{Q 50}\right) & & {[0.123]} & {[0.137]} & {[0.041]} & {[0.000]}\end{array}$

Note: Bootstrapped standard errors (using 100 replications) in parenthesis. P-values from $\chi^{2}$-test of coefficient equality with the median $(Q 50)$ regression coefficient are in brackets. Sample sizes are 85,753 (1a and $1 \mathrm{~b}$ ), 117,837 (2a), 116,365 (2b), 130,047 (3a), 101,635 (3b), 142,046 (4a) and 139,210 (4b). 
Table 7: Transmission mechanisms: Descriptive statistics

a) Incomes

\begin{tabular}{|c|c|c|c|c|c|c|}
\hline \multirow[b]{2}{*}{ Son variables } & & \multicolumn{5}{|c|}{ Sons with fathers in the following income fractile: } \\
\hline & & P0-90 & P90-95 & P95-99 & P99-99.9 & P99.9-100 \\
\hline \multirow[t]{2}{*}{ Income } & Mean & 289 & 394 & 452 & 581 & 1,498 \\
\hline & (S.d.) & $(206)$ & $(334)$ & $(466)$ & $(812)$ & $(4,453)$ \\
\hline \multirow[t]{2}{*}{ IQ } & Mean & 5.1 & 6.3 & 6.5 & 6.7 & 6.3 \\
\hline & (S.d.) & $(1.9)$ & $(1.7)$ & $(1.7)$ & $(1.6)$ & $(1.7)$ \\
\hline \multirow[t]{2}{*}{ Non-cog. skills } & Mean & 5.1 & 5.8 & 6.0 & 6.2 & 6.1 \\
\hline & (S.d.) & $(1.6)$ & $(1.6)$ & (1.6) & $(1.6)$ & $(1.7)$ \\
\hline \multirow[t]{2}{*}{ Net worth } & Mean & 311 & 647 & 944 & 2,575 & 6,387 \\
\hline & (S.d.) & $(912)$ & $(1,798)$ & $(2,803)$ & $(24,417)$ & $(16,208)$ \\
\hline \multirow[t]{2}{*}{ Financial assets } & Mean & 113 & 254 & 363 & 1,537 & 2,853 \\
\hline & (S.d.) & $(474)$ & $(887)$ & $(1,243)$ & $(24,454)$ & $(7,624)$ \\
\hline \multirow[t]{2}{*}{ Taxable wealth } & Mean & 28 & 111 & 210 & 554 & 2,488 \\
\hline & (S.d.) & (325) & $(775)$ & $(1,006)$ & $(2,321)$ & $(9,099)$ \\
\hline \multirow[t]{2}{*}{ Education years } & Mean & 11.8 & 13.4 & 13.8 & 14.4 & 13.8 \\
\hline & (S.d.) & $(2.0)$ & $(2.3)$ & $(2.4)$ & $(2.4)$ & $(2.4)$ \\
\hline $\mathrm{N}$ & & 97,519 & 5,416 & 4,300 & 941 & 101 \\
\hline
\end{tabular}

b) Earnings

\begin{tabular}{|c|c|c|c|c|c|c|}
\hline \multirow[b]{2}{*}{ Son variables } & & \multicolumn{5}{|c|}{ Sons with fathers in the following earnings fractile: } \\
\hline & & P0-90 & P90-95 & P95-99 & P99-99.9 & P99.9-100 \\
\hline Earnings & $\begin{array}{l}\text { Mean } \\
\text { (S.d.) }\end{array}$ & $\begin{array}{c}290 \\
(138) \\
\end{array}$ & $\begin{array}{c}383 \\
(229) \\
\end{array}$ & $\begin{array}{c}423 \\
(353) \\
\end{array}$ & $\begin{array}{c}477 \\
(338) \\
\end{array}$ & $\begin{array}{c}583 \\
(430) \\
\end{array}$ \\
\hline IQ & $\begin{array}{l}\text { Mean } \\
\text { (S.d.) }\end{array}$ & $\begin{array}{c}5.2 \\
(1.8)\end{array}$ & $\begin{array}{c}6.4 \\
(1.7)\end{array}$ & $\begin{array}{c}6.6 \\
(1.7)\end{array}$ & $\begin{array}{c}6.8 \\
(1.6)\end{array}$ & $\begin{array}{c}6.5 \\
(1.7)\end{array}$ \\
\hline Non-cog. skills & $\begin{array}{l}\text { Mean } \\
\text { (S.d.) }\end{array}$ & $\begin{array}{c}5.2 \\
(1.5) \\
\end{array}$ & $\begin{array}{c}5.9 \\
(1.6) \\
\end{array}$ & $\begin{array}{c}6.0 \\
(1.6) \\
\end{array}$ & $\begin{array}{c}6.3 \\
(1.5) \\
\end{array}$ & $\begin{array}{c}6.3 \\
(1.6) \\
\end{array}$ \\
\hline Net worth & $\begin{array}{l}\text { Mean } \\
\text { (S.d.) }\end{array}$ & $\begin{array}{c}307 \\
(928)\end{array}$ & $\begin{array}{c}677 \\
(2,019)\end{array}$ & $\begin{array}{c}877 \\
(1,949)\end{array}$ & $\begin{array}{c}1,363 \\
(3,805)\end{array}$ & $\begin{array}{c}3,627 \\
(8,175)\end{array}$ \\
\hline Financial assets & $\begin{array}{l}\text { Mean } \\
\text { (S.d.) }\end{array}$ & $\begin{array}{c}114 \\
(452)\end{array}$ & $\begin{array}{c}275 \\
(1,244) \\
\end{array}$ & $\begin{array}{c}350 \\
(1,174) \\
\end{array}$ & $\begin{array}{c}566 \\
(1,882) \\
\end{array}$ & $\begin{array}{c}1,999 \\
(5,483)\end{array}$ \\
\hline Taxable wealth & $\begin{array}{l}\text { Mean } \\
\text { (S.d.) }\end{array}$ & $\begin{array}{c}27 \\
(252) \\
\end{array}$ & $\begin{array}{c}123 \\
(863) \\
\end{array}$ & $\begin{array}{c}212 \\
(1,112) \\
\end{array}$ & $\begin{array}{c}364 \\
(1,512) \\
\end{array}$ & $\begin{array}{c}2,277 \\
(10,025)\end{array}$ \\
\hline Education years & $\begin{array}{l}\text { Mean } \\
\text { (S.d.) }\end{array}$ & $\begin{array}{l}11.9 \\
(2.0)\end{array}$ & $\begin{array}{l}13.5 \\
(2.3)\end{array}$ & $\begin{array}{l}13.9 \\
(2.3)\end{array}$ & $\begin{array}{l}14.6 \\
(2.3)\end{array}$ & $\begin{array}{l}14.0 \\
(2.2)\end{array}$ \\
\hline $\mathrm{N}$ & & 77,327 & 4,306 & 3,393 & 745 & 77 \\
\hline
\end{tabular}


Table 8: Mechanisms of transmission: top incomes

\begin{tabular}{|c|c|c|c|c|c|c|c|c|c|}
\hline \multirow[b]{2}{*}{$\begin{array}{l}\text { Father } \\
\text { income } \\
\text { fractiles }\end{array}$} & \multicolumn{9}{|c|}{ Dependent variables (different son outcomes): } \\
\hline & Income & IQ & Higl & h IQ & $\begin{array}{r}\text { Non } \\
\text { sk }\end{array}$ & $\begin{array}{l}\text { n-cog. } \\
\text { kills }\end{array}$ & $\begin{array}{l}\text { High non- } \\
\text { cog. skills }\end{array}$ & $\begin{array}{l}\text { Education } \\
\text { years }\end{array}$ & $\begin{array}{c}\text { High } \\
\text { Education }\end{array}$ \\
\hline \multirow[t]{2}{*}{ P0-90 } & 0.220 & 0.938 & \multirow{2}{*}{\multicolumn{2}{|c|}{$\begin{array}{c}0.097 \\
(0.003)\end{array}$}} & \multirow{2}{*}{\multicolumn{2}{|c|}{$\begin{array}{c}0.648 \\
(0.016)\end{array}$}} & 0.052 & 1.205 & 0.136 \\
\hline & $(0.004)$ & $(0.019)$ & & & & & $(0.002)$ & $(0.021)$ & $(0.003)$ \\
\hline \multirow[t]{2}{*}{ P90-95 } & 0.278 & 1.161 & \multirow{2}{*}{\multicolumn{2}{|c|}{$\begin{array}{c}0.249 \\
(0.102)\end{array}$}} & \multirow{2}{*}{\multicolumn{2}{|c|}{$\begin{array}{c}0.977 \\
(0.363)\end{array}$}} & 0.165 & 1.726 & 0.471 \\
\hline & $(0.129)$ & $(0.399)$ & & & & & $(0.077)$ & $(0.527)$ & (0.109) \\
\hline \multirow[t]{2}{*}{ P95-99 } & 0.244 & 0.751 & \multirow{2}{*}{\multicolumn{2}{|c|}{$\begin{array}{c}0.143 \\
(0.052)\end{array}$}} & \multirow{2}{*}{\multicolumn{2}{|c|}{$\begin{array}{c}0.646 \\
(0.180)\end{array}$}} & 0.150 & 1.723 & 0.339 \\
\hline & $(0.068)$ & $(0.183)$ & & & & & $(0.044)$ & $(0.270)$ & $(0.055)$ \\
\hline \multirow[t]{2}{*}{ P99-99.9 } & 0.606 & 0.017 & \multicolumn{2}{|c|}{-0.064} & \multicolumn{2}{|c|}{1.131} & 0.042 & -0.752 & 0.071 \\
\hline & $(0.181)$ & $(0.422)$ & \multirow{2}{*}{\multicolumn{2}{|c|}{ (0.125) }} & \multicolumn{2}{|c|}{$(0.377)$} & $(0.107)$ & $(0.615)$ & $(0.135)$ \\
\hline \multirow[t]{2}{*}{ P99.9-100 } & 0.959 & 0.027 & \multirow{2}{*}{\multicolumn{2}{|c|}{$\begin{array}{c}-0.116 \\
(0.095)\end{array}$}} & \multirow{2}{*}{\multicolumn{2}{|c|}{$\begin{array}{c}-0.900 \\
(0.419)\end{array}$}} & -0.115 & -0.377 & -0.013 \\
\hline & $(0.230)$ & $(0.357)$ & & & & & $(0.081)$ & $(0.512)$ & $(0.124)$ \\
\hline \multirow[t]{2}{*}{$\mathrm{N}$ (total) } & 108,277 & 108,277 & \multicolumn{2}{|c|}{108,277} & \multicolumn{2}{|c|}{108,277} & 108,277 & 108,277 & 108,277 \\
\hline & Net worth & $\begin{array}{c}\text { Log } \\
\text { Net worth }\end{array}$ & $\begin{array}{l}\text { Log Pos. } \\
\text { Net worth }\end{array}$ & Fina & & $\begin{array}{l}\text { Log Finan- } \\
\text { cial Assets }\end{array}$ & Tax wealth & $\begin{array}{c}\text { Log } \\
\text { Tax wealth }\end{array}$ & $\begin{array}{l}\text { Log Pos. } \\
\text { Tax wealth }\end{array}$ \\
\hline \multirow[t]{2}{*}{ P0-90 } & 44,576 & 0.227 & 1.125 & 64 , & & 1.166 & 30,372 & 0.324 & 0.312 \\
\hline & $(10,003)$ & $(0.021)$ & $(0.057)$ & $(5,3$ & & $(0.040)$ & $(3,020)$ & (0.033) & $(0.031)$ \\
\hline \multirow[t]{2}{*}{ P90-95 } & $1,717,360$ & 1.602 & 4.143 & 581 & & 2.240 & 579,264 & 3.895 & 3.693 \\
\hline & $(551,264)$ & $(0.366)$ & (1.249) & (228 & & $(0.746)$ & $(254,568)$ & (1.072) & (1.020) \\
\hline \multirow[t]{2}{*}{ P95-99 } & $1,133,324$ & 0.872 & 1.111 & 489 & & 1.289 & 607,793 & 3.795 & 3.451 \\
\hline & $(348,117)$ & (0.174) & (0.619) & (128 & 97) & $(0.346)$ & $(136,805)$ & (0.629) & (0.594) \\
\hline \multirow[t]{2}{*}{ P99-99.9 } & $6,412,201$ & 1.826 & 3.340 & 2,80 & 406 & 2.499 & $2,287,123$ & 7.847 & 7.395 \\
\hline & $(2,170,916)$ & $(0.432)$ & (1.327) & $(1,41$ & 553) & $(0.697)$ & $(850,186)$ & (1.763) & (1.713) \\
\hline \multirow[t]{2}{*}{ P99.9-100 } & $20,303,567$ & 1.684 & 3.198 & 12,19 & ,353 & 3.158 & $5,646,754$ & 5.767 & 5.753 \\
\hline & $(7,458,157)$ & $(0.336)$ & $(1.379)$ & $(4,280$ & 513) & $(0.544)$ & $(4,397,791)$ & $(2.166)$ & $(2.112)$ \\
\hline $\mathrm{N}$ (total) & 108,277 & 73,732 & 108,277 & 108 & & 108,277 & 108,277 & 102,515 & 108,277 \\
\hline
\end{tabular}

Note: The dependent variable is specified in column headings and independent variable is father income. Separate regressions are run for different father income fractiles, with $N$ showing the aggregate number of observations. Constant terms are suppressed. Robust standard errors are in parenthesis. High IQ, non-cognitive skills and education are dummy variables equal to one when sons are in roughly the top five percentiles in the respective distributions. Wealth variables are in Swedish currency or logged ditto. "Positive" wealth means that all observations with negative or zero wealth are replaced by one (which in log form becomes zero). For further details of variables and methods, see Table 1 and the text. 
Table 9: Mechanisms of transmission: top earnings

\begin{tabular}{|c|c|c|c|c|c|c|c|c|c|}
\hline \multirow[b]{2}{*}{$\begin{array}{l}\text { Father } \\
\text { earnings } \\
\text { fractiles }\end{array}$} & \multicolumn{9}{|c|}{ Dependent variables (different son outcomes): } \\
\hline & Earnings & IQ & High & IQ & $\begin{array}{r}\text { Nor } \\
\text { sl }\end{array}$ & $\begin{array}{l}\text { n-cog. } \\
\text { kills }\end{array}$ & $\begin{array}{l}\text { High non- } \\
\text { cog. skills }\end{array}$ & $\begin{array}{l}\text { Education } \\
\text { years }\end{array}$ & $\begin{array}{c}\text { High } \\
\text { Education }\end{array}$ \\
\hline \multirow[t]{2}{*}{ P0-90 } & 0.125 & 0.367 & \multicolumn{2}{|c|}{0.040} & & .212 & 0.021 & 0.553 & 0.066 \\
\hline & $(0.003)$ & $(0.015)$ & \multicolumn{2}{|c|}{$(0.003)$} & & $.012)$ & $(0.002)$ & $(0.017)$ & $(0.003)$ \\
\hline \multirow[t]{2}{*}{ P90-95 } & 0.335 & 0.954 & \multirow{2}{*}{\multicolumn{2}{|c|}{$\begin{array}{c}0.280 \\
(0.122)\end{array}$}} & & .748 & 0.158 & 1.058 & 0.298 \\
\hline & $(0.148)$ & $(0.455)$ & & & & .419) & $(0.094)$ & $(0.612)$ & $(0.130)$ \\
\hline \multirow[t]{2}{*}{ P95-99 } & 0.187 & 0.763 & \multicolumn{2}{|c|}{0.163} & & .599 & 0.166 & 1.600 & 0.330 \\
\hline & $(0.072)$ & $(0.213)$ & \multicolumn{2}{|c|}{$(0.061)$} & & $.210)$ & $(0.053)$ & $(0.311)$ & $(0.065)$ \\
\hline \multirow[t]{2}{*}{ P99-99.9 } & 0.558 & -0.146 & \multicolumn{2}{|c|}{-0.049} & & .987 & 0.061 & -0.528 & 0.029 \\
\hline & $(0.218)$ & (0.541) & \multicolumn{2}{|c|}{$(0.164)$} & & $.476)$ & $(0.135)$ & $(0.798)$ & $(0.170)$ \\
\hline \multirow[t]{2}{*}{ P99.9-100 } & 0.507 & -0.187 & \multirow{2}{*}{\multicolumn{2}{|c|}{$\begin{array}{l}-0.191 \\
(0.222)\end{array}$}} & & 1.141 & -0.032 & -1.630 & -0.267 \\
\hline & $(0.290)$ & $(0.651)$ & & & & $.152)$ & $(0.220)$ & $(1.025)$ & $(0.238)$ \\
\hline \multirow[t]{2}{*}{$\mathrm{N}$ (total) } & 85,848 & 85,848 & \multicolumn{2}{|c|}{85,848} & & 5,848 & 85,848 & 85,848 & 85,848 \\
\hline & Net worth & $\begin{array}{c}\text { Log } \\
\text { Net worth }\end{array}$ & $\begin{array}{l}\text { Log Pos. } \\
\text { Net worth }\end{array}$ & & & $\begin{array}{l}\text { Log Finan- } \\
\text { cial Assets }\end{array}$ & s & $\begin{array}{c}\text { Log } \\
\text { Tax wealth }\end{array}$ & $\begin{array}{l}\text { Log Pos. } \\
\text { Tax wealth }\end{array}$ \\
\hline \multirow[t]{2}{*}{ P0-90 } & $-133,761$ & -0.094 & 0.088 & & & 0.201 & 2,811 & -0.087 & -0.073 \\
\hline & $(12,394)$ & $(0.013)$ & $(0.042)$ & & & $(0.027)$ & $(2,204)$ & $(0.031)$ & $(0.029)$ \\
\hline \multirow[t]{2}{*}{ P90-95 } & $1,518,510$ & 1.426 & 4.005 & 72 & & 2.372 & 549,901 & 3.841 & 3.704 \\
\hline & $(467,287)$ & $(0.411)$ & (1.456) & $(29$ & 88) & $(0.845)$ & $(208,487)$ & (1.257) & (1.202) \\
\hline \multirow[t]{2}{*}{ P95-99 } & 898,129 & 0.751 & 0.996 & 31 & & 1.194 & 487,796 & 3.383 & 3.107 \\
\hline & $(229,907)$ & (0.187) & $(0.707)$ & $(12$ & 99) & $(0.387)$ & $(121,232)$ & $(0.724)$ & $(0.683)$ \\
\hline \multirow[t]{2}{*}{ P99-99.9 } & $2,158,355$ & 0.641 & 3.723 & 51 & & 2.577 & 398,132 & 5.862 & 5.555 \\
\hline & $(1,200,581)$ & $(0.509)$ & (1.640) & $(46$ & 38) & $(0.825)$ & $(356,693)$ & (2.120) & (2.032) \\
\hline \multirow[t]{2}{*}{ P99.9-100 } & $12,619,482$ & 1.620 & 1.752 & 8,07 & 958 & 3.103 & $15,946,230$ & 7.471 & 6.215 \\
\hline & $(8,927,638)$ & $(0.781)$ & (3.101) & $(6,35$ & & (1.143) & $(13,186,815)$ & (3.636) & (3.396) \\
\hline $\mathrm{N}$ (total) & 85,848 & 59,816 & 85,848 & & & 85,848 & 85,848 & 81,415 & 85,848 \\
\hline
\end{tabular}

Note: The dependent variable is specified in column headings and independent variable is father earnings. Separate regressions are run for different father earnings fractiles, with $N$ showing the aggregate number of observations. Constant terms are suppressed. Robust standard errors are in parenthesis. High IQ, non-cognitive skills and education are dummy variables equal to one when sons are in roughly the top five percentiles in the respective distributions. Wealth variables are in Swedish currency or logged ditto. "Positive” wealth means that all observations with negative or zero wealth are replaced by one (which in log form becomes zero). For further details of variables and methods, see Table 1 and the text. 


\begin{tabular}{llc}
\hline & \multicolumn{2}{c}{ Number of observations } \\
\cline { 2 - 3 } & Income & Earnings \\
\hline 1. All sons, born in Sweden in 1960-1967 and part of the multigenerational & 151,148 & 151,148 \\
register, registered as living in Sweden all years 1996-2005. & 150,902 & 148,612 \\
2. All sons in 1 and with at least one positive income (earnings) observation. & 142,716 & 126,045 \\
3. All sons in 1 and with 10 positive income (earnings) observations. & 140,710 & 124,379 \\
$\begin{array}{l}\text { 4. All sons in 3 with a known biological father. } \\
\text { 5. All sons in 4 with a biological father who was registered in Sweden all years } \\
\text { 1974-1979. }\end{array}$ & 134,673 & 119,300 \\
$\begin{array}{l}\text { 6. All sons in 5 with a biological father who has at least one positive income } \\
\text { (earnings) observation. }\end{array}$ & 134,599 & 118,638 \\
$\begin{array}{l}\text { 7. All sons in 6 with a biological father who has positive income (earnings) } \\
\text { observations all years 1974-1979. }\end{array}$ & 130,047 & 101,635 \\
$\begin{array}{l}\text { 8. All sons in 7 for whom we also observe IQ, non-cognitive skills and educa- } \\
\text { tion. }\end{array}$ & 108,277 & 85,848 \\
\hline \hline
\end{tabular}


Figure 1: Income transmission across the distribution

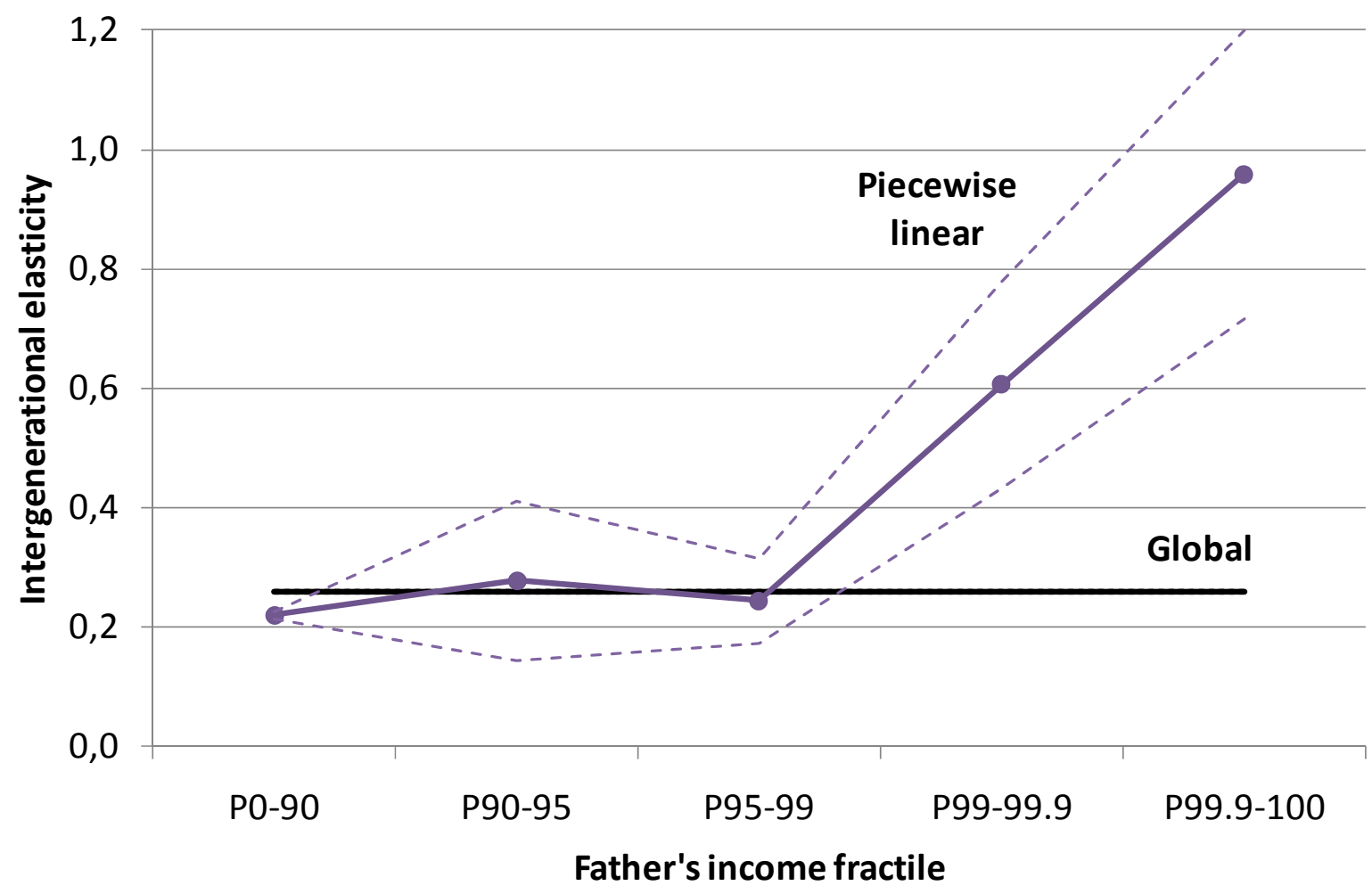

Note: Intergenerational elasticities and corresponding error bands are based on results reported in Table 2.

Figure 2: Earnings transmission across the distribution

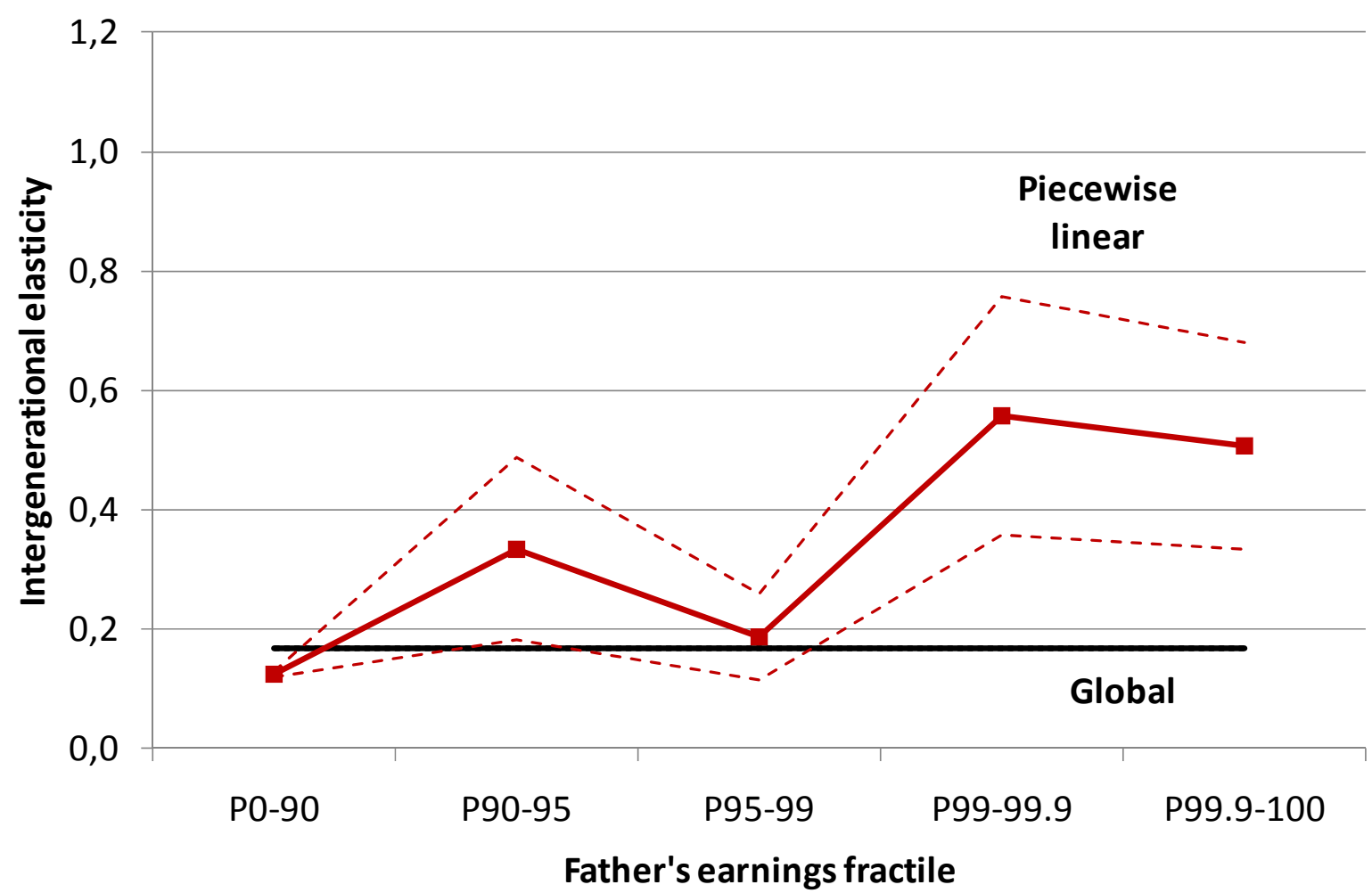

Note: Intergenerational elasticities and corresponding error bands are based on results reported in Table 2. 
Figure 3: Mechanisms of income transmission
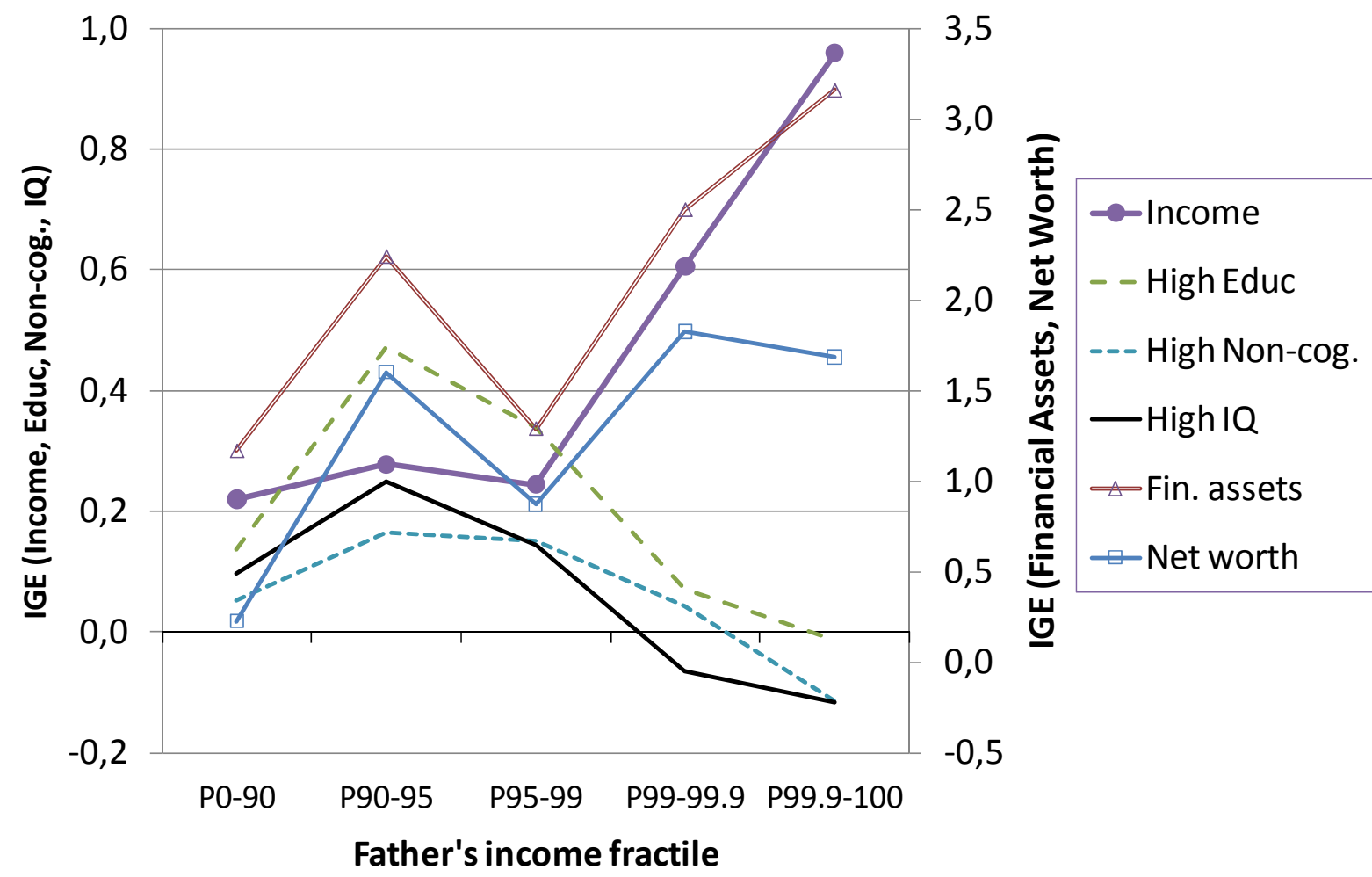

1,5

1,0

- High IQ

0,5
0,0

$\triangle$ Fin. assets

$\square-$ Net worth

Note: The figure shows estimated intergenerational elasticities as reported in Table 8.

Figure 4: Mechanisms of earnings transmission

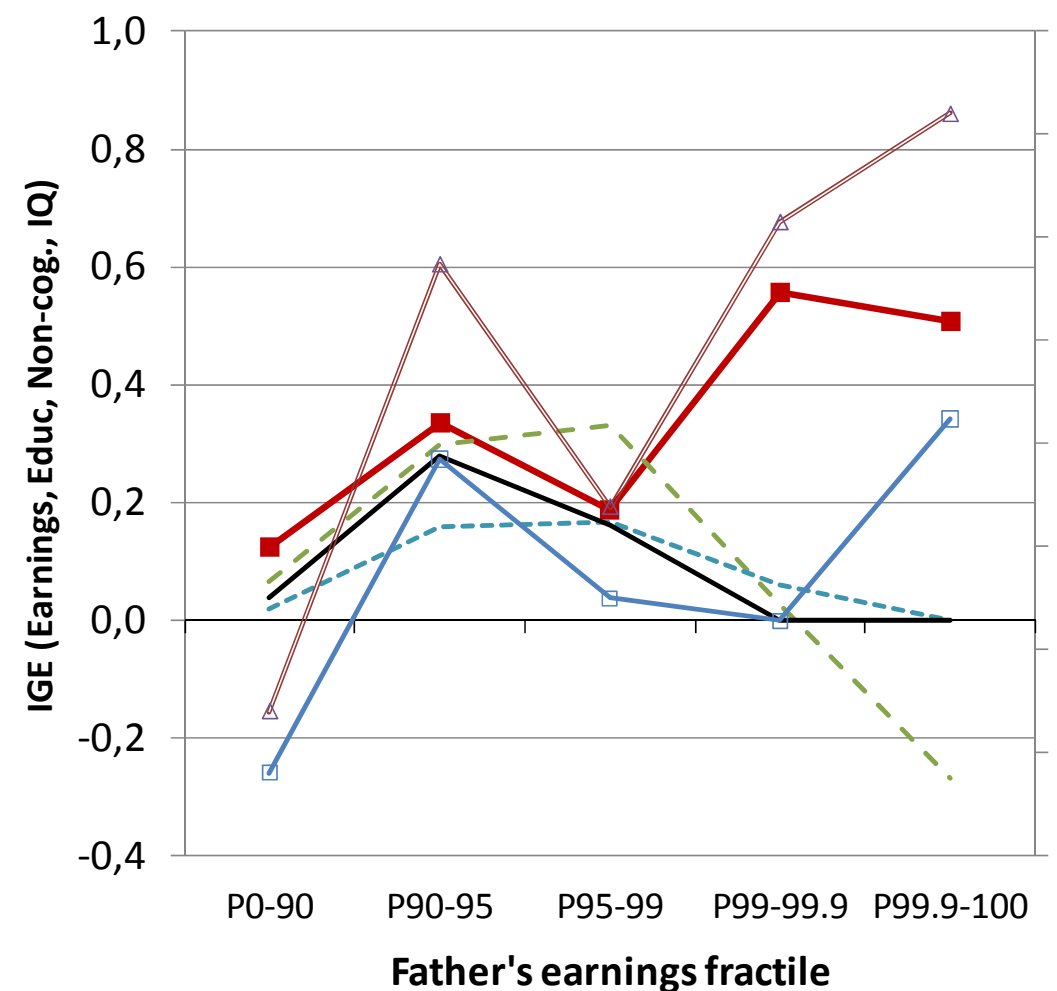

3,0

2,5

$\rightarrow$ Earnings

2,0

- - High Educ

1,5

--- High Non-cog.

1,0

- High IQ

$\sqrt{0}$

$\triangle$ Fin. assets

0,5

든 $\square$ Net worth

0,0

峲

$-0,5$

Father's earnings fractile

Note: The figure shows estimated intergenerational elasticities as reported in Table 9. 